\title{
VODENJE IN POVELJEVANJE V 12. SOŠKI OFENZIVI
}

\section{COMMAND AND CONTROL IN THE TWELFTH ISONZO OFFENSIVE}

Povzetek Vodilni na evropskih generalštabih so med prvo svetovno vojno uporabljali tradicionalni način vodenja in poveljevanja, ki je od podrejenih zahteval predvsem poslušnost ter natančno izpolnjevanje ukazov. Na bojišču se je kmalu pokazalo, da je bil tak sistem za vodenje vojsk neprimeren in vzrok za marsikatero zamujeno priložnost. Prvi so novosti v vodenju in poveljevanju uvedli Nemci ter jih v praksi uspešno preizkusili v 12. soški ofenzivi.

Ključne 12. soška ofenziva, vojaško vodenje in poveljevanje, kabinetno poveljevanje, besede poveljevanje s poslanstvom - Auftragstaktik.

Abstract In the period of the First World War, European general staff leaders used the traditional model of military command and control, which demanded from their subordinates obedience and precise fulfilment of commands. The situation in the battlefields soon showed that the system was inappropriate and resulted in many lost opportunities. The Germans were the first to use a new model of military command and control and they successfully applied it in the Twelfth Isonzo Offensive.

Key words Twelfth Isonzo Offensive, military command and control, chateau generalship, mission command-Auftragstaktik.

Uvod 12. soška ofenziva je ena izmed vojaških operacij, v kateri je prišlo do bistvenih sprememb v procesu vojaškega vodenja in poveljevanja, ki je do tedaj številnim v prvo svetovno vojno vpletenim generalštabom povzročal veliko težav ter preglavic. Velika vojna se je namreč že zgodaj spremenila v rovovsko vojno, v kateri so se med nasprotnimi državami vzpostavile frontne bojne linije strateškega obsega. Nobena izmed v vojno vpletenih strani kljub zavzetemu prizadevanju ni bila zmožna prebiti 
fronte in napredovati globoko v zaledje sovražne države. To je spodbujalo vodilne na generalštabih, da so razmišljali, s katerimi vojaškimi novostmi bi dosegli premoč na bojišču in končno prekinili dotedanje stanje.

Do jeseni leta 1917 so Italijani na soški fronti izvedli že 11 ofenziv, med katerimi so večje uspehe in ozemeljske osvojitve dosegli le v 6. ter 11. ofenzivi. Cilja avstroogrske vojske na tej fronti sta bila zagotavljati obrambo in preprečiti, da bi italijanska vojska prodrla globlje na ozemlje monarhije. Za Avstro-Ogrsko je bilo italijansko bojišče tretje bojišče in na njem je imela le obrambne cilje. Namen Italijanov je bil zavzeti Trst in Ljubljano ter prodreti čim globlje na nasprotnikovo ozemlje. Vojski ostarele monarhije je uspelo zagotavljati obrambo proti Italiji kar dve leti, potem pa je postalo jasno, da država ne bo več sposobna zadrževati močnejšega sovražnika in da je mogoč celo razpad večnacionalne vojske, ki ni več verjela v skupno prihodnost. $\mathrm{V}$ težkih razmerah se je donavska monarhija zatekla po pomoč k svoji zaveznici Nemčiji. Nemškemu vojaškemu vrhu je bilo jasno, da grozi razpad avstro-ogrske vojske, kar mora preprečiti, če želi doseči svoje vojaške cilje spomladi leta 1918, zato je ponudil pomoč.

\section{METODOLOŠKA IN TERMINOLOŠKA ZASNOVA RAZISKAVE}

$\mathrm{V}$ raziskavi smo uporabili metodo analize zgodovinopisnega gradiva, metodo analize znanstvenih del in metodo primerjave pridobljenih podatkov. Izhajali smo iz hipoteze, da je bil proces vojaškega vodenja in poveljevanja med prvo svetovno vojno neučinkovit, in iz hipoteze, da so Nemci v 12. soški ofenzivi uporabili nov ter učinkovitejši sistem vodenja in poveljevanja.

$\mathrm{V}$ prispevku smo obravnavali proces vojaškega vodenja in poveljevanja. Avtorji danes večinoma ločijo med terminoma vodenje in poveljevanje, pri čemer ima pojem vodenje širši, poveljevanje pa ožji pojmovni obseg. Lubi opredeljuje vojaško vodenje kot proces usmerjanja vojaških enot in posameznikov z namenom uresničevanja ciljev vojaške organizacije (Lubi, 2007, str. 96). Posebnost vojaškega vodenja oziroma poveljevanja je poveljniški odnos, za katerega je značilna hierarhičnost, komuniciranje med nadrejenimi in podrejenimi pa poteka v obliki povelj, ukazov ter direktiv. Za neuresničitev ukaza nadrejenega se v vojni izrekajo sankcije, ki po ostrini presegajo povprečne družbene standarde (Lubi, 2007, str. 97-98). Veliko avtorjev pojmuje razliko med vojaškim vodenjem in poveljevanjem v tem smislu, da gre pri poveljevanju za eno izmed faz vodstvenega procesa v vojaški organizaciji, ki se nanaša predvsem na ukazovanje (Lubi, 2007, str. 98-99). Po Vojaški doktrini Slovenske vojske je poveljevanje »pristojnost, predpisana z zakonom, ki jo potrebuje poveljujoči za načrtovanje, organiziranje, vodenje in kontrolo dodeljenih sil« (Petelin (ur.), 2006, str. 63). 


\section{VOJAŠKO VODENJE IN POVELEVANJE V PRVI SVETOVNI VOJNI}

Proces vojaškega vodenja in poveljevanja je med prvo svetovno vojno temeljil na načelih, ki so veljala v vojaških organizacijah že stoletja pred tem. Čeprav se je vojaška tehnologija v nekaj stoletjih bistveno spremenila, pa na področju vodenja in poveljevanja ni bilo izvedenih temeljitih sprememb. Zaradi tehnološkega napredka $\mathrm{v}$ sistemu zvez (telegraf in telefonska ter radijska zveza) so v začetku 20. stoletja vodilni na evropskih generalštabih verjeli, da bodo z novimi tehnološkimi pridobitvami dogajanje na bojišču popolnoma obvladovali ter nadzorovali. Pričakovali so, da bodo ob pomoči sodobne komunikacijske opreme generali lahko poveljevali iz zaledja in povsem obvladovali razmere na bojišču. Večinoma so verjeli v čudežno moč telegrafske, telefonske in radijske zveze. Niso se še zavedali številnih pomanjkljivosti sredstev zvez, predvsem v bitkah, ko so enote potrebovale hitre ukaze, ti pa zaradi prekinjenih telefonskih zvez in zamudnega šifriranja ter dešifriranja niso mogli priti pravočasno. Vera $\mathrm{v}$ novo tehnologijo je prepričala vodilne na generalštabih, da bodo generali lahko iz varnega zaledja učinkovito vodili armade na terenu. Že prvo leto vojne se je pokazalo, da so v vojnih operacijah vodilni na generalštabih hitro izgubili stik z dogajanjem na fronti. Čeprav je bil tudi na področju komunikacij tehnološki napredek izjemen, pa je temeljil na žični telefonski povezavi, ki je pogosto zatajila. Popolna izguba nadzora nad dogajanjem je lahko med ofenzivo trajala tudi po več dni, na bojišču pa je posledično prihajalo do zmešnjave. Vera generalštabov v tehnologijo, ki naj bi jim na področju zvez omogočila nadzorovati in usmerjati dogajanje na bojišču, se je izkazala za enega glavnih vzrokov za vojaški neuspeh. Armadam so poveljevali generali, ki zaradi omejitev tehnologije niso imeli popolnega nadzora nad dogajanjem na bojišču (Creveld, 1985, str. 153-154).

Med prvo svetovno vojno so evropske vlade uniformirale milijone moških in jih poslale na bojišče. V praksi se je uveljavil pojem uniformiranega ljudstva. Številčnost vojsk je presegla dotedanje izkušnje. Do takrat svet tako masovne mobilizacije moških za vojaško službo še ni videl. Generali so morali voditi in poveljevati milijonom podrejenih ter skrbeti za transport ter logistično in sanitetno oskrbo, kar je zahtevalo veliko organizacijskega prizadevanja, prilagajanja in sprotnega učenja od poveljujočih. Vojska Avstro-Ogrske je na primer v štirih letih mobilizirala kar 31,5 odstotka odraslega moškega prebivalstva (Beckett, 2001, str. 207). Po drugi strani so se generali spoprijemali z zelo hitrim tehnološkim napredkom, ki je v naglici presegal vse, kar se je na svetu v tehnološkem smislu dogajalo do tedaj (Morris, 2017). Kljub zelo velikemu tehnološkemu napredku in mobilizaciji nacionalnih ekonomij za vojaške namene ter mobilizaciji milijonov moških za vojaško službo so se evropske vojske ustalile na frontah strateškega obsega in nobena izmed njih ni bila zmožna premagati svojega nasprotnika. V vojno vpleteni strani sta iskali vse mogoče načine, da bi prebili fronto. Na obeh straneh so razvijali nove vrste orožja in urili na novo vpoklicane vojake, vendar to ni bilo dovolj. Nujen je bil tudi premik v sistemu vodenja in poveljevanja (Lilaropoulos, 2010, str. 153). Glavna težava takratnega sistema poveljevanja in kontrole je bila, da višji vojaški poveljniki niso dovolj hitro zaznali, da so njihove enote dosegle preboj frontne linije, niti niso zaznali, kje se je 
preboj zgodil, da bi lahko pravočasno poslali na ta sektor okrepitve. Preboji so se torej dogajali, izkoristiti pa jim jih ni uspelo. Posledično so generalštabi pošiljali na bojišče vse več uniformiranih moških in človeških žrtev je bilo vedno več, vojaškega uspeha pa ne (Morris, 2017).

V nekaj letih je postalo jasno, da je tradicionalni koncept vojaškega vodenja in poveljevanja pomanjkljiv ter neuspešen. Glavna težava je bila, da vojaška poveljstva niso razumela razmer na bojišču, zato so izdajala ukaze, ki so bili zastareli, zakasneli in si podrejeni z njimi niso mogli veliko pomagati. Na bojišču je posledično prihajalo do zmede. Tak sistem vojaškega vodenja in kontrole je bil nezanesljiv že, ko je šlo za poveljnike vodov v bitki, generali pa so bili pogosto popolnoma brez nadzora nad dogajanjem na bojišču prav v trenutkih, ko bi bili njihovi ukazi najbolj nujni. Zmeda v vojaškem vodenju tako ni obstajala le na najvišjih vojaških ravneh, temveč se je širila navzdol do enot najnižje ravni. Problematika glede vojaškega vodenja je imela izjemne razsežnosti. V javnosti in vojaških vrstah na obeh vojskujočih se straneh so zato poveljujoče na skrivaj primerjali z osli, podrejene vojake pa z levi. V skladu s tem mnenjem so se vojaki na frontah prve svetovne vojne borili kot levi, slediti pa so morali poveljem oslov (Terraine, 2008). Načela tradicionalnega vojaškega vodenja so bila očitno zastarela in vojska, ki je želela doseči napredek na bojišču, je morala iznajti tudi nov koncept vojaškega vodenja. Odločitve bi se morale po novem sprejemati tam, kjer so imeli vojaški poveljniki najboljši pregled nad dogajanjem na bojišču. Prav tako bi se prilagodljivost na bojišču lahko dosegala le s prenosom pobude in odgovornosti na nižje vojaške poveljnike (Wolf, 2010, str. 88). Tradicionalna vojaška hierarhija je zavirala nujne novosti na tem področju (Beckett, 2001, str. 162). Tudi na nižjih ravneh ni bil proces vodenja in poveljevanja nič bolj preprost kot na višjih. Glavni izzivi vojaškega vodenja so izhajali iz dejstva, da so morali častniki in podčastniki voditi ter poveljevati vojakom, ki so z opravljanjem vojaške službe izgubili svobodo, osebno udobje in ugodje ter so se morali podrediti nenehni življenjski nevarnosti, negotovosti, revščini in ukazom nadrejenih. Naloga častnikov je bila, da vzpostavijo notranjo kohezijo v enotah in privzgojijo enotam pripadnost celotni vojski (Sheffield, 2005, str. 42-44).

\section{TRADICIONALNI KONCEPT VOJAŠKEGA VODENJA IN POVELJEVANJA}

Tradicionalni koncept vodenja so uporabljale vojske od časov, ko so se ljudje prvič organizirali v vojaške formacije 2500 let pred našim štetjem, do prve svetovne vojne (Morris, 2017). Tradicionalni koncept je podeljeval vojaško avtoriteto generalom in častnikom, ki so poveljevali podrejenim vojakom oziroma podčastnikom. Od podrejenih je zahteval popolno poslušnost in ubogljivost $\mathrm{v}$ odnosu do navodil ter povelj nadrejenih poveljnikov. Tradicionalni koncept vodenja in poveljevanja sta uporabljali obe vojski, ki sta se spopadali na soški fronti, torej tako italijanska kot tudi avstro-ogrska. Med vojskama so bile velike razlike. Italijanska vojska je bila bolje oborožena in preskrbljena kot vojska monarhije, po drugi strani pa so imeli avstro-ogrski vojaki že bojne izkušnje $\mathrm{z}$ drugih front, česar pa italijanski vojaki v 
začetku vojne z Avstro-Ogrsko niso imeli. Motiviranost vojakov je bila večja na strani Avstro-Ogrske, saj so slovenski, hrvaški, srbski in bošnjaški vojaki verjeli, da branijo svoje domove pred italijanskimi napadalci. Dejstvo, da so se Nemci, Hrvati, Slovenci, Srbi in Bošnjaki izkazali za najbolj zanesljive vojake na soški fronti, je izkoriščalo tudi avstrijsko vojaško vodstvo, ki je te narode pogosteje mobiliziralo v primerjavi z drugimi narodi monarhije (Beckett, 2001, str. 207). ${ }^{1}$

Italijanska vojska težav z narodnostno heterogenostjo ni imela, imela pa je hude težave s socialno heterogenostjo moštva. Razlike v izobrazbi nabornikov s severa in juga Italije so bile zelo velike. Vojaki z juga Italije so v vojski lahko pričakovali le najnižje vojaške položaje $\mathrm{v}$ pehoti, kar jih je posledično sililo v razmišljanje, da so žrtve višje razvitih vojaških oligarhij s severa države. Socialna nasprotja so bila zelo velika in so se v vojski izrazito slabo kazala. Avgusta 1917 je italijanska vojska vpoklicala stavkajoče delavce iz torinskih tovarn streliva, saj delavci v tovarnah vojaške industrije niso imeli pravice do stavke, kar je še dodatno vneslo negativno vzdušje v vojsko in se v končni fazi pokazalo tudi v kolapsu italijanske armade pri Kobaridu (Beckett, 2001, str. 209).

V 12. soški ofenzivi so Italijani uporabili izrazito avtokratski ter centraliziran sistem vodenja in poveljevanja, kakršen je bil značilen za njihovo armado že ves čas vključenosti v vojno ter tudi že v obdobju pred tem. Temeljil je na bogati vojaški tradiciji Apeninskega polotoka, zaznamovalo pa jo je predvsem vojaško vodenje $\mathrm{z}$ ustrahovanjem in okrutnim kaznovanjem vojakov, ki so se prekršili. Avtokratsko vojaško vodenje se je uveljavilo že $\mathrm{v}$ antični rimski vojski in koncept vodenja $\mathrm{z}$ ustrahovanjem je zagovarjal tudi Niccolo Machiavelli (Cheney, 2016). ${ }^{2}$

Kabinetni stil poveljevanja, imenovan tudi chateau generalship, sta uporabljala tako poveljnik italijanskega generalštaba general Cadorna kot vrhovni poveljnik avstroogrskega generalštaba general Conrad von Hötzendorf (Beckett, 2001, 163-164). ${ }^{3}$ General Cadorna, ki je vodil italijansko vojsko do 12. ofenzive na Soči, je bil produkt

\footnotetext{
Narodnostna heterogenost avstro-ogrske vojske se je na vzhodni fronti in v Srbiji pokazala kot oteževalna okoliščina pri zagotavljanju učinkovitega vojaškega vodenja in poveljevanja, na soški fronti pa jo je vojaško vodstvo izkoristilo. Na soški fronti težave z dezerterstvom in prestopanjem vojakov na drugo stran niso imele take razsežnosti kot na obeh drugih frontah monarhije. Predvsem slovanski narodi namreč niso bili integrirani $v$ monarhijo tako, da bi zagotavljali popolno podporo in predanost državnim ciljem. V težkih razmerah na bojišču so te težave povzročale množične prestope v nasprotnikovo vojsko in dezerterstvo predvsem na vzhodni fronti. Vojaki slovanskih narodov so na bojiščih vzhodne fronte pogosto ugotavljali, da se ne želijo več boriti proti svojim slovanskim bratom. Rusija se je te težave zavedala in je obljubila češkemu narodu samostojnost, potem ko bi porazila nemško vojsko. Ruska vojska je oblikovala češko legijo, ki so jo sestavljali avstro-ogrski dezerterji, prestopniki in vojni ujetniki češkega ter slovaškega rodu (Kent, 2013, str. 160).

2 Ob koncu 19. stoletja si je italijanska vojska pridobila sloves manj sposobne vojske, saj je šlo za edino kolonialno silo, ki jo je v 19. stoletju premagala vojska staroselcev $v$ Afriki in ji preprečila njene kolonialne namene med prvo etiopsko vojno leta 1895 in 1896. V glavni bitki etiopsko-italijanske vojne je bila skoraj polovica italijanskih vojakov ubita, ranjena in zajeta. Ceprav je vojska glavnega krivca za neslavni poraz prepoznala v generalu Orestu Baratieriju, pa večjih ukrepov v smislu izboljšav vojaškega vodenja in poveljevanja ni uvedla (Perry, 1996, str. 195). Italijanska vojska tudi ni upoštevala 400 let starih svaril Machiavellija, da so se italijanske vojske v preteklosti slabo borile zaradi šibkosti svojih vodij (Thompson, 2008, str. 317).

3 General Conrad von Hötzendorf je napredoval v maršala 25. novembra 1916 in ostal poveljnik avstro-ogrskega generalštaba do 1. marca 1917, ko ga je zamenjal general Arz von Straßenburg.
} 
stare evropske vojaške šole (Simčič, 2000, str. 139). Njegova generacija poveljnikov se je šolala na primerih Napoleonovih vojn in vojn 19. stoletja. V ospredju so bile Napoleonove bitke $\mathrm{s}$ hitrimi in globokimi manevrskimi prodori $\mathrm{v}$ nasprotnikovo zaledje ter ofenzivnimi in napadalnimi akcijami. V 11 ofenzivah, ki jih je izvedla italijanska vojska na Soči, je bila v vlogi napadalke. V 12. ofenzivi so se razmere spremenile in italijanska vojska se je znašla v obrambnem položaju. Navdušenje, ki je spremljalo italijansko vojsko v začetnih ofenzivah, se je do leta 1917 poleglo zaradi zelo velikih človeških žrtev in razmeroma majhnih ozemeljskih pridobitev. Motivacija vojakov se je zmanjšala in v obupu so želeli generali ter častniki ohranjati vojaško disciplino z okrutnim kaznovanjem vojakov. Po podatkih Tackena je Cadorna odobril 750 usmrtitev kot kazni za vojaške prekrške ter zamenjal 217 generalov in visokih častnikov, preden so ga odpustili. V letih od 1915 do 1918 so italijanska vojaška sodišča obravnavala 330.000 primerov vojakov, ki so bili obtoženi kriminalnih dejanj, od tega pa jih je bilo 61 odstotkov spoznanih za krive (Tacken, 2015). To dokazuje, da italijansko vojaško vodstvo ni zaupalo svojim vojakom, zato se je zatekalo predvsem k negativnim načinom motiviranja. Italijanski častniki so bili vzgojeni v brezpogojni poslušnosti in za nedisciplino so jim grozile hude kazni. Nesoglasja so se po drugi strani dogajala tudi v avstro-ogrski vojski, vendar odziv nanje ni bil tako skrajen kakor v italijanski. General Svetozar Boroević de Bojna ${ }^{4}$ je bil poveljnik 5. armade in je v svojih zamislih obrambe večkrat prihajal v nesoglasja z nadrejenimi. $V$ teh primerih jim je zagrozil z odhodom v pokoj, če vojaških načrtov ne bodo uresničili v skladu $\mathrm{z}$ njegovimi zamislimi. Zaradi zmag na ruski fronti $\mathrm{v}$ Karpatih leta 1914 in 1915 je postal karizmatična osebnost in na soški fronti se je z uspešnimi boji njegova karizma še povečala, zato je avstrijsko vojaško vodstvo njegovo prošnjo za upokojitev zavrnilo ter ga obdržalo za poveljnika armade na Soči (Nečak, 2010, str. 21 in 22).

Pozicijska vojna in številne žrtve so v prvi svetovni vojni povzročale veliko težav vojaškemu vodenju ter poveljevanju na vseh v vojno vpletenih straneh. Razmere na bojišču, na katerem je bilo na sto tisoč človeških žrtev, so povzročale zmanjšanje motivacije za bojevanje, v najtežjih primerih pa tudi dezerterstvo. Najbolj skrajne metode za zatiranje dezerterstva je uporabljala italijanska vojska. General Cadorna je uvedel decimiranje kot kazen za strahopetnost in uporništvo v vojski, pri čemer so poveljniki lahko ukrep sprejeli, kadar je bila zaradi teh vzrokov ogrožena celotna vojska oziroma vojaška enota. Pri tem se je zahtevalo, da se izvrši smrtna kazen nad vsakim desetim v enoti, ki je bila kaznovana, takoj na kraju, kjer se je prekršek zgodil. Decimiranje se je izvajalo razmeroma pogosto in Cadorna se je tega zavedal, vendar se mu ni zdelo v ničemer problematično oziroma se mu je ukrep zdel nujen za zagotavljanje discipline ter morale v vojski. Italijanska vojska je bila edina, ki je

\footnotetext{
4 Svetozar Boroević de Bojna je bil avstro-ogrski poveljnik, ki se je rodil leta 1856 v srbski pravoslavni družini krajišnikov v vasi Umetić na Hrvaškem. Njegov priimek se zapisuje na dva načina, in sicer kot Boroević ali Borojević. On se je podpisoval kot Boroević in tudi uradno je bil v avstrijskih virih tako imenovan. Njegov plemiški naziv se prav tako zapisuje na dva načina, in sicer kot de Bojna ali von Bojna. Glede na to, da je prejel plemiški naziv v ogrskem delu države, kjer se je plemstvo ponašalo s predpono de, je bolj točen zapis de Bojna, $v$ virih pa se pogosteje navaja kot von Bojna. V feldmaršala je napredoval 1. februarja 1918, kar je bil izjemen uspeh za poveljnika slovanskega porekla v Avstro-Ogrski.
} 
uporabljala tako krute in nepravične ukrepe kaznovanja svojih vojakov. Britanska, francoska, nemška in druge vojske tako okrutnega kaznovanja niso poznale, čeprav so se tudi spoprijemale z dezerterstvom ${ }^{5}$, zlasti ko se na primer vojaki niso pravočasno vrnili z vojaškega dopusta. Smrtnih obsodb je bilo v italijanski vojski veliko in so presegle dogajanje na tem področju v drugih vojskah. Aprila 1917 je italijanska vojska uveljavila ukrep smrtne kazni za vsakega vojaka, ki je za več kot tri dni zamudil vrnitev z dopusta. Od junija tega leta je bila družinam dezerterjev odvzeta državna pomoč. Avgusta 1917 je italijansko vrhovno poveljstvo skrajšalo čas, ko se je nedovoljena odsotnost še dopuščala, na le 24 ur. Tudi kazni za nepokorščino so bile v italijanski vojski hujše kot drugod. Kaznovali so lahko že primere, ko so podrejeni oficirji dvignili glas nad nadrejenimi ali z njimi govorili v neprijetnem tonu. Vojake, ki so se v pismih domačim pritoževali čez svoje častnike ali zmanjševanje obrokov hrane, je lahko doletela kazen šest mesecev ječe. Odzivi na strogo in okrutno kaznovanje so bili opazni predvsem v zmanjšanju morale vojakov na bojišču. Število žrtev decimiranja še danes ni znano, ker italijanska vlada po vojni ni hotela objaviti podatkov o tej temi. Vrhovna komanda je za zmanjšanje morale avgusta 1917 obtožila socialiste in pacifiste, ki naj bi želeli, da Italija izgubi vojno. Italija je v celoti delovala kot policijska oziroma vojaška država že od leta 1915. Strokovnjaki danes ugotavljajo, da je bila Italija med vojno toliko pod vplivom socialistov kakor druge evropske države in da so bile obtožbe generalštaba ter vlade brez realne podlage (Thompson, 2008, str. 269-271). Italijanski tisk je bil preveč patriotski, da bi obsodil okrutno kaznovanje vojakov, italijanska vlada pa ni imela dovolj volje, da bi ga ukinila. Edini vir pritiska na Cadorno je bil parlament. Socialisti so zahtevali od Cadorne, da neha streljati nedolžne ljudi, in parlamentu so generala predstavili kot sto let zaostalega poveljnika, ki z nasiljem in streljanjem vzpostavlja vojaško disciplino, toda tudi ti pritiski niso bili uspešni. Še celo po porazu v 12. soški ofenzivi italijanska vlada ni bila pripravljena obsoditi decimiranja, dokler se vojna ni končala. Po vojni so italijanske oblasti vendarle ugotovile, da je bilo decimiranje divjaški ukrep, ki ga ne more upravičiti noben razlog (Thompson, 2008, str. 268). Ukrepi discipliniranja, ki jih je uvedla italijanska vojska, so povzročali, da so se vojaki bali svojih nadrejenih in da so se tudi oficirji bali svojih nadrejenih. Zanje je Cadorna predstavljal celo večjega sovražnika kot centralne sile (Mesesnel, 1987, str. 278). Uvedba strahovlade v italijanski vojaški organizaciji ni prinesla pozitivnih rezultatov. Strah pred kaznimi je predvsem uničevalno vplival na medsebojno zaupanje v odnosu med nadrejenimi in podrejenimi, ki je za uspehe na bojišču bistvenega pomena. Decimiranje je bil najbolj krut kaznovalni ukrep, kar so ga poznale vojske v Evropi, in z vidika vojakov predvsem nepošten ter nepravičen.

\footnotetext{
Francozi so se aprila 1917 po neuspešnem napadu vzdolž reke Aisne, v katerem so izgubili več kot 100.000 vojakov, začeli upirati vojaškim poveljem. Več kot 50 divizij ni hotelo zapustiti rovov, dezerterstva so bila množična, 1000 mož pa je zasedlo vlak in prisililo strojevodjo, da jih je odpeljal v Pariz, kjer so pričakovali, da bodo prepričali vlado, naj sklene premirje. Do Pariza niso prišli, saj so jih ustavili lojalni francoski vojaki in jih prisilili, da so se vrnili na fronto. Vojaške oblasti so po teh dogodkih sodile več kot 100.000 vojakom in 23.000 izmed teh je bilo kaznovanih zaradi kršenja vojaške discipline (Kent, 2013, str. 159). Podobne težave so se pojavile na vzhodni fronti med ruskimi vojaki februarja 1917, ko je bila vojska osiromašena s 195.000 dezerterji. Zaradi boljševistične revolucije se je število dezerterjev leta 1917 še povečevalo in doseglo število 365.000 (prav tam, str. 164).
} 
Po drugi strani so bile vlade v drugih evropskih državah do streljanja svojih vojakov zelo zadržane. Britanska vojaška sodišča so zaradi dezerterstva usmrtila 306 vojakov. V nemški vojski je 150.000 vojakov dezertiralo in veliko so jih ujeli, usmrtili pa le 18. Francozi so zaradi dezerterstva usmrtili nekaj več kot 600 vojakov, je pa tudi francoska vojska poznala primer decimiranja, ki so ga izvedli v alžirski četi, ki je zavrnila povelje za napad leta 1914 (Shot at Dawn). V nasprotju z italijansko vojsko je britanska vojska na primer namenjala večji poudarek medsebojnemu zaupanju $\mathrm{v}$ odnosu med vojakom in oficirjem in le v redko kateri enoti je veljalo, da bi se vojaki bolj bali orožja nadrejenega častnika od orožja nasprotnikov. Medsebojno zaupanje se je izkazalo $\mathrm{v}$ težavnih razmerah kot pomemben dejavnik, ki je preprečeval množično dezerterstvo (Sheffield, 2005, str. 149).

\section{DECENTRALIZACIJA VOJAŠKEGA VODENJA IN POVELEVANJA}

Zaradi neuspehov na bojišču so bila vojaška vodstva prisiljena iskati nov način tudi na področju vodenja in poveljevanja, da bi vendarle presegla dotedanje stanje na bojišču in prebila fronto. Leta 1916 je trajalo od osem do deset ur, da so sporočila, ukazi in navodila z generalštabov dosegli divizijske poveljnike na terenu (Beckett, 2001, str. 165). V vojno so leta 1914 vstopile države, ki so temeljile na sodobnem državljanstvu in izobraženih ter kritično razmišljajočih državljanih (Morris, 2017). Vojaški aparat je temeljil na starih načelih, ki so od vojakov zahtevala brezpogojno poslušnost ukazov. Nov koncept, pri katerem bi potekalo vodenje vojne ne le od zgoraj navzdol, temveč tudi od spodaj navzgor, je bil nujen (Morris, 2017). Nova metoda je nastala v prusko-nemškem okolju v 19. stoletju zaradi zagotavljanja večje učinkovitosti vojske na bojišču (Erminger, 2010). Že pruski general in nemški maršal von Moltke se je v 19. stoletju zavedal, da s takratno tehnologijo ni mogoče zagotoviti zadostnega pretoka informacij med vojaško enoto ter nadrejenim poveljstvom. Ukazi niso mogli biti izpolnjeni dovolj hitro glede na razmere na bojišču. Po drugi strani se je zavedal, da razen začetka vojne poteka vojne ni mogoče predvideti, saj proces vključuje veliko nepredvidljivih dejavnikov. Rešitev težave prenosa ukazov in dejavnika nepredvidljivosti je videl predvsem v zmanjševanju obsega navodil za podrejene enote ter v povečevanju njihovega samostojnega delovanja v skladu s skupnim vojaškim ciljem. V nemški terminologiji se novi pristop imenuje Auftragstaktik (Creveld, 1985, str. 146). Izraz je mogoče zavajajoč, ker vsebuje besedo taktika, v resnici pa se ne nanaša na taktiko, temveč na metodo vodenja in poveljevanja, ki temelji na izpolnjevanju poslanstva oziroma naloge, torej vodenje s poslanstvom (Führen mit Auftrag) ${ }^{6}$. Bistvo novega koncepta je, da podrejeni izbira med več različicami načina izpolnitve naloge oziroma ukaza glede na razmere na bojišču. Ta novi koncept pojmuje nižje vojaške poveljnike kot razmišljujoče ljudi, saj so se sposobni prilagoditi razmeram na bojišču, ki jih lahko obrnejo v korist izpolnjevanja naloge

\footnotetext{
Nemški izraz za nasprotje koncepta Auftragstaktik je Befehlstaktik in se nanaša na model vodenja, ki preprečuje kakršno koli pobudo podrejenih. V modelu vodenja Befehlstaktik se od podrejenih zahtevata popolna poslušnost danim ukazom in čakanje na ukaz poveljnika, preden začnejo bojno delovati (Muhm, 2017).
} 
oziroma vojaškega cilja. Koncept je zahteval kratka povelja in navodila, ki puščajo več možnosti podrejenemu, da se prilagodi razmeram na bojišču in izpolni ukaz s čim večjim uspehom (Erminger, 2010, str. 7).

Bistvo te nove doktrine sta podelitev in priznanje pravice do pobude nižjim vojaškim poveljnikom. Nemška vojska je ta novi pristop opredelila v konceptih Führung nach Direktive in Auftragstaktik. Ta pristop je najbolj trajna zapuščina von Moltkeja starejšega. Moltke je izhajal iz stališča, da je pokornost načelo, človek pa je nad njim. Vztrajal je pri zahtevi, da nadrejena poveljstva usposobijo svoje enote, da bodo cilj vojaške akcije toliko razumele, da bodo lahko na bojišču samostojno ukrepale. Namen tega je bil spodbuditi pobudo za delovanje nižjih taktičnih enot in jo usmeriti v pravi cilj (Bungay, 2011).

Auftragstaktik temelji na metodologiji izdajanja ukazov, po katerih je podrejenim določeno, kaj morajo narediti, ne da bi jim povedali, kako to narediti. Najpomembnejši del te metodologije je namera nadrejenega, ki temelji na viziji zaželenega končnega stanja (Potočnik, 2014). Pogoji za uspešnost vodenja s poslanstvom so medsebojno zaupanje med podrejenimi in nadrejenimi vojaškimi poveljniki, standardizirani postopki operativnega delovanja, enotna izurjenost, zanesljivost, discipliniranost in sposobnost samostojnega delovanja (Wolf, 2010, str. 89). Auftragstaktik vključuje dejstvo, da so sodobne države v začetku 20. stoletja vzgajale posameznike, ki so bili izobraženi v sistemu splošne šolske obveznosti in duhu nacionalnih zamisli (Morris, 2017). Motivacijski element, ki je pripomogel k boljšim rezultatom na bojišču, je nacionalna zavest, ki so jo imeli oboroženi meščani (Walther, 2010, str. 52). To je koncept Auftragstaktik prevzel, ko je dovolil nižjim vojaškim poveljnikom samoiniciativno delovanje v skladu z namero nadrejenih častnikov.

Zaradi neuspehov nemške vojske na bojiščih prve svetovne vojne je general Ludendorff nemškemu generalštabu ukazal razviti uspešnejšo taktiko za napad, da bi z njo presegli vojno jarkov in prešli v uspešno ofenzivno delovanje. Novo taktiko je razvijal stotnik Willy Martin Rohr. Nadrejeni so mu dovolili vse pri razvijanju nove napadalne taktike in tudi orožje, moštvo, poskusne uniforme ter opremo. Enote so bile specializirane za napadno delovanje in so jih poimenovali Stoßtruppen oziroma udarne enote. Te je leta 1917 začel vključevati v boj na vzhodni fronti stotnik Georg Bruchmüller. Enote so uporabljale taktike infiltracije, v napadu pa presenečenje, ki so ga usmerjale na artilerijska gnezda in poveljniške centre. Svoje uspehe je predstavil generalu Oskarju von Hutieru in ta je uporabil novo taktiko ter novi način poveljevanja v bitki za Rigo 1. septembra 1917. Nova taktika in novi koncept vojaškega vodenja sta se izkazala za tako uspešna, da so nemške enote Rigo osvojile v le dveh dneh. Nemški generalštab je bil navdušen in je zahteval množično vključevanje novih bojnih enot tudi na drugih frontah. Novi sistem vojaškega vodenja je omogočal manjšim enotam, da so se vrinjale v nasprotnikove položaje in izkoriščale razmere na bojišču ter šibkost nasprotnikove obrambe (Sweet, 2000, str. 36). Ko so nižji vojaški poveljniki dobili priložnost, da izkoristijo razmere na bojišču, in ko so spoznali, da jim nadrejeno poveljstvo zaupa, se je povečala tudi njihova 
motivacija za bojevanje in pozitivni učinek je imel dvojno moč. ${ }^{7}$ Čeprav so vojno vodili generalštabi, se je taktika razvijala ne le v smeri od zgoraj navzdol, temveč tudi od spodaj navzgor. Tako je bila taktika jurišnih enot oziroma Stoßtrupptaktik rezultat razvoja na najnižji taktični ravni kot odgovor na dogajanje na bojišču $\mathrm{v}$ središču bitk. Tem prvim poskusom prebiti fronto na lokalni ravni so sledili poskusi s specializiranimi enotami in na koncu so nastale nove doktrine. Zamisel jurišnih enot je temeljila na manjših visoko motiviranih enotah, katerih borci bi se lahko enačili z ničejanskim nadčlovekom. Od teh vojakov se ni več pričakovalo, da bodo le izpolnjevali povelja, temveč, da bodo izkoristili razmere na bojišču v svojo korist in pogumno napredovali na nasprotnikove položaje (Bull, 2007, str. 160-162).

\section{12. OFENZIVA NA SOŠKI FRONTI}

12. ofenziva na soški fronti je bila na tej fronti prva ofenziva, v kateri so centralne sile prešle iz obrambnega vojaškega delovanja v napad. Razlog za spremembo vojaškega delovanja je bil predvsem v kritičnem položaju avstro-ogrske vojske, ki je po 11. soški ofenzivi spoznala, da s svojimi silami ne bo več mogla braniti tega dela fronte z Italijo, zaradi teženj nekaterih delov monarhije po odcepitvi pa je bila ogrožena tudi enotnost vojske. Avstrijska zaveznica Nemčija je bila zaskrbljena glede AvstroOgrske, saj se je bala, da bo Karel I., ki je prevzel habsburško žezlo po smrti Franca Jožefa I. 21. novembra 1916, sklenil separatni mir z nasprotniki (Mosier, 2001, str. 291). Avgusta 1917 je Cadorna izvedel ofenzivo z 51 divizijami in v napadu vztrajal kar mesec dni (11. soška ofenziva), avstro-ogrska obramba pa je komaj vzdržala. Nemčija je svoji zaveznici ponudila pomoč, saj je bilo vztrajanje Avstro-Ogrske v vojaških akcijah bistvenega pomena za nadaljnje nemške vojaške operacije. Nemčija je pričakovala, da bodo Italijani na soški fronti pred koncem leta izvedli še eno ofenzivo in ob kolapsu Avstro-Ogrske bi Nemčija ostala brez zaveznice, zato so Nemci ponudili pomoč (Thompson, 2008, str. 295).

Ofenziva je bila skrbno načrtovana in temeljito pripravljena, poimenovali pa so jo Zvestoba v orožju (Waffentreue). Nalogo za izvedbo ofenzive je dobila 14. armada, ki ji je poveljeval general Otto von Below, načelnik štaba pa je bil Konrad Kraft von Dellmensingen, ki je bil specialist za gorsko bojevanje. Armada je vključevala osem avstro-ogrskih in sedem nemških divizij. Posebnost te ofenzive je bila predvsem izbira lokacije, saj se je vojaško vodstvo odločilo, da bo izvedlo ofenzivo

\footnotetext{
Nova nemška taktika je temeljila na presenečenju, prikritih premikih enot le ponoči in lažnih scenarijih, s katerimi naj bi preslepili nasprotnikovo vojsko. Oblikovali so manjše taktične pehotne enote, ki so temeljile na 14 do 18 vojakih, in jih poimenovali jurišne enote (Stoßtruppen). Te enote so imele nalogo, da se ognejo močnejši obrambi nasprotnika in poiščejo šibke točke v obrambi, jih izkoristijo ter prodrejo čim globlje v nasprotnikovo obrambo. Nova taktika je bila prvič uporabljena v bitki za Rigo septembra 2017. Poimenovali so jo po generalu Oskarju von Hutieru, ki je vodil napad na Rigo, Hutierova taktika (Dupuy, 2011, str. 226-228). Bistvo nove taktike sta decentralizacija poveljevanja in napadanje v manjših skupinah. Poveljniki so razložili nižjim častnikom cilj njihove vojaške naloge, ti pa so potem sami glede na razmere na bojišču odločali, kako bodo nalogo opravili. Ta novi način poveljevanja se je izkazal kot zelo uspešen, ker ni več prihajalo do zapoznelih ukazov. Častniki so na bojišču iskali najbolj ranljive predele nasprotnikove obrambe in jih napadli (Sweet, 2000, str. 37).
} 
na 30 kilometrov dolgem odseku fronte med Plešo in Tolminom, čeprav je šlo za visokogorski teren, za katerega je v tem obdobju veljalo, da je za vojskovanje v zimskih mesecih neuporaben. Namen zaveznikov je bil potisniti italijanske enote do reke Tilment, torej od 30 do 40 kilometrov v notranjost, kar je bil za tiste čase zelo ambiciozen načrt. Primerjava moči obeh nasprotnikov kaže, da so imeli Italijani premoč z vsaj 41 divizijami na tej lokaciji, napadalci pa so imeli 33 divizij (Mosier, 2001, str. 292). Centralne sile so ofenzivo zasnovale na uporabi presenečenja, novih taktičnih prijemov v obliki infiltracije, na uporabi plinskega napada in izkoriščanju šibkosti v italijanski obrambi. Namen ofenzive je bil onesposobiti italijansko vojsko, da bi pred pomladjo ali celo pred poletjem 1918 izvedla novo ofenzivo. Velikega preboja centralne sile niso pričakovale (Thompson, 2008, str. 294-296).

Ofenzivo pogosto poimenujejo kot čudež pri Kobaridu. Ta izrazje pravzaprav napačen v obeh terminih, ki ju vključuje. Po eni strani je bila ofenziva skrbno načrtovana in pripravljena ter njen uspeh ni bil posledica čudeža, po drugi strani pa napad, ki je omogočil hiter prodor centralnih sil, ni bil izveden pri Kobaridu, temveč pri Tolminu in Bovcu (Beyeri, 1998). Priprave na ofenzivo so bile temeljite. Poveljniki so si pred napadom podrobno ogledali fronto in pripravili posebne karte ter načrte napada, tako da niso ničesar prepustili naključju. Prevoz čet in materiala v bližino bojišča se je začel v drugi polovici septembra ter je trajal do ofenzive. Enote so bile razporejene v vseh večjih krajih okoli bojišča, in sicer v Beljaku, Celovcu, Kranjski Gori, Ljubljani, na Jesenicah, v Kranju, Bohinju ter drugod. Na bojišče so jih premestili le nekaj dni pred ofenzivo. Premeščanje enot je potekalo ponoči in nemške enote so deloma opremili z avstrijskimi uniformami oziroma pokrivali. Nemško letalstvo je nadzorovalo zračni prostor in preprečevalo italijanskemu letalstvu, da bi preletavalo avstrijske položaje. Do 24. oktobra so centralne sile premestile na območje med Tolminom in Bovcem toliko enot, da so imele premoč nad Italijani v razmerju $3: 2$ glede na število moštva ter veliko premoč v artileriji, bojnih strupih in avtomatski oborožitvi (Thompson, 2008, str. 297).

Avstrijska obveščevalna služba je v prvem delu leta 1917 razvozlala italijanski sistem kodiranja, zato so imele centralne sile natančne podatke o položaju italijanskih enot. Centralne sile so se zavedale, da so komunikacije na severnem delu soškega bojišča zelo slabe in redke. Kraft je ocenjeval, da je italijanska obramba v severnem Posočju tako slaba, da bi se z njenim uničenjem široko odprla italijanska fronta od Gorice do Karnijskih Alp. Nemci so menili, da bi od osem do deset divizij na Tolminskem in tri dodatne na Bovškem zadostovale za preboj fronte. Novo taktiko je predlagal avstrijski general Alfred Krauss, ki je že leta 1916 zaman prepričeval Conrada, da je treba napasti po dolinah. Nemci so njegov predlog sprejeli in načrtovali napad po dolinah ter obkoljevanje visokih položajev nasprotnika. Cadorna je od leta 1915 uporabljal ustaljeno taktiko, s katero je osvajal visoke vrhove in položaje na njih ohranjal za vsako ceno. Obrambo je postavljal na visoke točke in z njih nadzoroval dogajanje v dolinah. Obramba v dolinah na italijanski strani je bila slaba, saj Cadorna ni niti pomislil, da bi nasprotniki uporabili nasprotno logiko in najprej napadli doline (Thompson, 2008, str. 296-297). 
Čeprav so Italijani dobili od avstrijskih dezerterjev podatke o kraju in času ofenzive ter nemškem sodelovanju, so se jim zdeli preveč nenavadni, da bi jim verjeli. Cadorna se je v času pred ofenzivo posvečal političnemu delovanju, saj je bil njegov vojaški položaj ogrožen zaradi hudih kritik, ki jih je dobival od socialistov in liberalcev v italijanskem parlamentu. Sredi oktobra je šel z ženo na dopust v Benetke in na položaj se je vrnil prerojen. Zima se je že skoraj začela in Cadorna je pričakoval avstrijsko ofenzivo šele leta 1918 (Thompson, 2008, str. 298). V okolici Vidma je še kratek čas pred ofenzivo bival vrhovni poveljnik italijanske vojske kralj Vittorio Emanuelle III. 22. oktobra je Cadorna pospremil kralja na Kobariški Stol in ugotovila sta, da ni pričakovati ničesar posebnega na tem delu fronte (Simčič, 2000, str. 127).

\section{VODENJE IN POVELJEVANJE V 12. SOŠKI OFENZIVI}

24. oktobra ob 2. uri so centralne sile začele artilerijski napad na 30 kilometrov dolgem odseku fronte med Bovcem in Tolminom. Artilerijski napad je bil tako silovit, da niti nemški veterani, ki so bili priča Verdunu in Sommi, niso videli česa takega. Italijanska 2. armada je na sektorju med Tolminom in Rombonom vzdrževala le deset divizij, saj je vrhovno poveljstvo ocenjevalo, da so gore zadostna obramba same po sebi. Doline so Italijani bolj opazovali z vrhov, namesto da bi jih v resnici branili z živo silo. General Pietro Badoglio je poveljeval XXVII. korpusu, katerega del je bila 19. divizija, ki je nadzorovala Tolmin in okolico. General Badoglio je že 10. oktobra dobil ukaz, naj premakne večino vojakov na linijo zahodno od Soče in okrepi obrambne položaje. Odlašal je 12 dni, preden je izvedel ukaz. Poveljniku artilerije je naročil, naj ne napada brez njegove odobritve. Ta poveljnik je 24. oktobra ob 2.30 zahteval dovoljenje za napad in Badoglio je odgovoril: »Imamo nabojev le za tri dni!« Ob 6.30 je bila povezava med poveljnikom korpusa in poveljnikom artilerije odpravljena, oddaljena pa sta bila pet kilometrov. Poveljnik artilerije se je držal ukazov in ni napadal na tolminskem sektorju. Čeprav je bil Badoglio eden glavnih krivcev za polom v 12. ofenzivi, je jeseni leta 1917 napredoval. Njegovo povelje je omogočilo nasprotnikom, da so napredovali z maršem po cesti in nekateri prvi dan prišli 25 kilometrov v italijansko notranjost, kar je bil za čas frontalnega bojevanja edinstven uspeh (Thompson, 2008, str. 301). Začetni preboj in uspeh pri Tolminu ter uspešen plinski napad pri Bovcu so dali centralnim silam zagon za nadaljnje prodiranje. Pri tem so uporabljali poveljevanje s poslanstvom, saj so nižje taktične enote dobile pooblastila, da v svojem rajonu delujejo glede na trenutne bojne razmere. Poveljniki centralnih sil so opravili skoraj vse zahtevne taktične in operativne naloge. Podporočnik je tako z manjšo skupino vojakov zavzel Matajur. Ježo in Stol sta zavzela poveljnika bataljona. Bataljonski poveljnik je pravočasno zavzel most pri Krminu. Uspeh ofenzive je v marsičem temeljil na posameznih četnih in bataljonskih poveljnikih, ki so s svojo domiselnostjo ter prizadevnostjo širili prvotno določene cilje in prodrli še enkrat dlje, kot je bilo prvotno načrtovano (Mesesnel, 1987, str. 276).

Cadorna je na dan začetka ofenzive spal v Vidmu, 40 kilometrov oddaljenem od Bovca. Zbudil se je ob svojem običajnem času, torej ob 5. uri, in mirno pozajtrkoval. 
Prve tri ure ofenzive je Cadorna prespal. Zjutraj je izvedel za bojno delovanje nasprotnika in bil prepričan, da je slabo vreme z meglo ter ledenim dežjem v korist italijanski obrambi. Ob 6. uri so mu javili, da je druga obrambna črta v Zgornjem Posočju pod močnim artilerijskim ognjem. Kljub tej informaciji je bil še vedno prepričan, da gre za slepilni napad in da bo sledil glavni napad v južnem oziroma srednjem delu soške fronte, zato je enotam ukazal, naj varčujejo s strelivom. Ob 7.30 so se avstro-ogrske enote razporedile po dolini pod Rombonom. Naslednji dan so dosegle Žago, ki je bila prazna, saj se je italijanska obramba umaknila na gorato območje. Ob 16. uri so Nemci zavzeli Kobarid. Telefonske linije vzdolž fronte so bile prekinjene in informacije o dogajanju na fronti so v Videm prihajale $\mathrm{z}$ večurno zamudo (Thompson, 2008).

27. oktobra malo po polnoči je Cadorna izvedel za padec Breškega Jalovca in ob 2.50 je izdal ukaz za umik 2. ter 3. italijanske armade čez reko Tilment. Temu je sledil še umik 4. armade iz Karnijskih Alp. 27. oktobra zjutraj se je začel splošen umik italijanske vojske. Na cestah je bilo več kot dva milijona italijanskih vojakov in približno 400.000 civilnih beguncev (Thompson, 2008, str. 316). Urejen umik se je kmalu spremenil v paničen beg. Številni častniki so se umaknili z avtomobili in prepustili vojake usodi. Ti so se najprej umikali z vso opremo, potem pa so začeli odmetavati vse, kar jih je oviralo pri begu. Jarki ob cestah so bili polni vozov, opreme, topov in najrazličnejšega vojaškega materiala. Vojska je razpadala, veliko častnikov je pobegnilo in odločali so tisti, ki so bili tam. Vojaki so bili prepričani, da je vojne konec in da bodo lahko šli domov. Cadorna se je z vrhovnim poveljstvom 27. oktobra umaknil iz Vidma v Treviso in se je šele po večdnevnem molku oglasil s položajev na Piavi. Bil je jezen na 2. armado, ki se ni hotela bojevati in mogoče zato ni organiziral umika na Tilment. Vojsko je prepustil njeni iznajdljivosti. Njegovo poveljstvo je povsem izgubilo nadzor nad umikom. Podrejeni so delovali brez pooblastil in enote so bile prepuščene brezglavemu umiku. Vrhovno poveljstvo je molčalo, zato so bili poveljniki podrejenih enot demoralizirani. Ukazi, ki so prihajali z višjih poveljstev, so bili nerealni in protislovni, saj so se razmere na bojišču zaradi hitrega napredovanja nasprotnikovih sil hitro spreminjale. To je še dodatno zmanjševalo zaupanje nižjih poveljstev in vojakov v sposobnosti vojaškega vodstva (Simčič, 2000, str. 115, 147). Obupan poskus italijanske vojske vzpostaviti obrambo na reki Tilment je 2. novembra propadel in centralne sile so prodirale še naprej proti zahodu (Mosier, 2001, str. 294). 4. novembra je Cadorna ukazal umik na reko Piavo. Centralnim silam je v ofenzivi uspelo prodreti 140 kilometrov v notranjost italijanske države. Zavzele so tudi vse ozemlje, ki ga je italijanska vojska s trudom pridobila v 11 ofenzivah na Soči.

Cadorna je imel avgusta 1917 v Benečiji 51 divizij, konec oktobra pa jih je italijansko vrhovno poveljstvo imelo le še 41. Zaradi katastrofalnih razmer se je britanski premier Lloyd George odpravil v Italijo, da bi ugotovil, ali italijanska vlada še vztraja v vojni. Ugotovil je, da je bilo v italijanski vojski že oktobra zelo veliko mrtvih, ranjenih, pogrešanih (dezerterjev) in zajetih. Novembra se je število žrtev še povečalo, tako da se italijanska vojska ni mogla več opreti na svoje vojaške sile 
(Mosier, 2001, str. 295). Konec novembra so Britanci okrepili italijansko fronto s štirimi in Francozi s šestimi novimi divizijami. Bali so se, da bi Italija izstopila iz vojne in bi Avstro-Ogrska okrepila nemške sile na zahodni fronti. Frontna linija se je tako ustalila na Piavi in tam vztrajala do jeseni leta 1918. Ofenziva se je končala šele 2. decembra 1917, ko so Nemci začeli transportirati svoje enote nazaj v Nemčijo, kar je trajalo do februarja 1918. Prodor se je ustavil tudi zato, ker centralne sile niso bile več sposobne zagotavljati logistične oskrbe svojih enot. Enote so bile poleg tega izčrpane in jim je primanjkovalo streliva (Lexikon Erster Weltkrieg).

Odziv italijanskih vojakov na prodor centralnih sil je general Cadorna prikazoval kot "generalni štrajk» (Simčič, 2000, str. 138). Sistem vodenja in poveljevanja, ki je temeljil na pretirani okrutnosti, se je izkazal kot neučinkovit in je bistveno pripomogel k razpletu 12. ofenzive. Množice italijanskih vojakov so se vdajale nasprotnikom brez boja in enega glavnih krivcev lahko iščemo v sistemu vodenja in poveljevanja. $\mathrm{V}$ italijanski vojski je bilo $40.000 \mathrm{mrtvih}$ in ranjenih pripadnikov, 293.000 vojakov je bilo zajetih, od 350.000 do 400.000 vojakov pa se je razbežalo v notranjost države. Vojska je izgubila 3150 kosov zaplenjenega artilerijskega orožja. Od 65 pehotnih divizij jih je ostalo le še 33, torej dobra polovica (Farina, 1998). Dezerterstvo med pripadniki italijanske vojske v 12. ofenzivi spada med eno najbolj množičnih v sodobni zgodovini vojskovanja in je bilo tako obsežno, da bi lahko centralne sile napredovale še globlje v italijansko zaledje, vendar so se ustavile zaradi zagotavljanja logistične oskrbe, ki se je z napredovanjem vse bolj oddaljevala. Le počasi so se italijanski vojaki vrnili v svoje enote in spet vzpostavili učinkovito obrambo (Kent, 2013, str. 160).

Sistem vodenja in poveljevanja tudi na strani centralnih sil ni deloval brezhibno. Centralne sile niso pričakovale tako obsežnega preboja fronte, kot se je zgodil. Boroevićeva 1. armada na Krasu in 2. armada na Banjščici bi morali napasti italijansko 3. armado, pa se to ni zgodilo zaradi slabih povezav med poveljniki, utrujenosti in mikavnosti plenjenja. Tako je italijanska 3. armada v urejenem stanju prečkala Tilment konec oktobra.

Italijansko vodstvo je generala Cadorno na zahtevo britanskega premiera 8. novembra 1917 odstavilo in ga zamenjalo z generalom Armandom Diazom. Cadorna je bil po vojni zaradi poraza v 12. ofenzivi hudo kritiziran, ne glede na to pa ga je Benito Mussolini leta 1924 povišal v čin maršala. General Cadorna je kot razlog za poraz v 12. ofenzivi navajal splošno stavko, strahopetnost in izdajstvo italijanskih vojakov, fašistični režim pa je v času med vojnama kot razlog za poraz navajal komunistične zamisli, ki naj bi se širile med italijanskimi vojaki in jih spodbujale k vdaji ter malodušju. ${ }^{8}$ Komunisti so razlagali dogodek kot zmago proletariata v splošni vojaški stavki (Farina, 1998). Danes strokovnjaki menijo, da je šlo pri 12. ofenzivi za vojaški poraz, za katerega je treba iskati vzroke v italijanski vojski. Glavni razlog je v vodstvu

Po fašistični razlagi je bila prva svetovna vojna temelj sodobne Italije oziroma krvavi ritual, v katerem se je italijanski narod ponovno ustvaril (Thompson, 2008, str. 326). 
italijanske vojske, ki ni bilo pripravljeno na morebitna presenečenja nasprotnikov. Vojaki se za vojaško stavko niso odločili zaradi strahopetnosti ali socialističnih zamisli, temveč je šlo za spontan upor proti vojni, kakršno sta vodila Cadorna in italijanska vlada. Kako močno se je ta vojaški poraz vtisnil v zavest italijanskega naroda, nam pove italijanski pregovor, ki se uporablja še danes: »To je bil Kobarid,« kar pomeni, da je šlo za popoln polom (Thompson, 2008, str. 294).

\section{DECENTRALIZACIJA VODENJA IN POVELJEVANJA DANES}

Vprašanje izbire med centraliziranim in decentraliziranim sistemom vojaškega vodenja in poveljevanja ostaja aktualno še danes. Moltkejev sistem vodenja je danes zanimiv ne le za vojaške teoretike, temveč ga preučujejo tudi civilni strokovnjaki s področja menedžmenta. Prednost njegovega koncepta je, da če podrejena enota izgubi stik z nadrejenim poveljstvom, si lahko še naprej prizadeva za izpolnitev svoje bojne naloge. $Z$ vidika teorije menedžmenta to pomeni, da je nesmiselno osredotočati se na podrobna navodila podrejenim v organizacijski shemi in je bolj funkcionalno, da se jim prepusti, da sami najdejo najboljši način za izpolnitev cilja organizacije. Na najvišji ravni naj bodo torej menedžerske usmeritve kratke in jedrnate (Bungay, 2011).

Po drugi strani sodobna vojaška tehnologija omogoča strog nadzor nad posameznimi vojaki in enotami ter nenehno kontrolo njihovega delovanja. Sodobno bojevanje zato omejuje vpliv koncepta Auftragstaktik na vojaške operacije. Tehnologija, ki omogoča satelitsko sledenje vsakemu vojaku, daljinsko vodena letala in daljinsko vodeni izstrelki niso v prid načelom Auftragstaktik in poudarjajo pomen centralizirano vodenega bojevanja. Bojevanje tudi danes zahteva možnost, da enote nižje taktične ravni na svojo pobudo izvedejo operacijo v skladu s poveljnikovo namero. Tako ameriška Army Doctrine Publication (ADP) 6-0 iz leta 2012, Mission Command, vključuje koncept Auftragstaktik v model poveljevanja s poslanstvom. V skladu s tem dokumentom morajo dati vojaški voditelji svojim podrejenim čim večjo svobodo pri opravljanju naloge in nasprotno morajo podrejeni opraviti nalogo v skladu z namero poveljnika (Gunther, 2012). Čeprav imajo danes nekatere države visoko tehnologijo, ki omogoča učinkovito centralizirano vodenje, se je treba zavedati, da nobena tehnologija ni vsemogočna in lahko v bojnih razmerah odpove, zataji ali jo uniči nasprotnik in v tem primeru stari koncept Auftragstaktik še vedno pomeni rešitev v sili, ki jo je treba predvideti že pred začetkom bojnega delovanja. Tudi slovenska Vojaška doktrina vključuje poveljevanje na podlagi poslanstva in zahteva razumevanje namere poveljnika (Petelin (ur.), 2006, str. 63).

Sodobno bojevanje temelji na manjših, visoko usposobljenih enotah, opremljenih z visoko tehnologijo, v njih pa je vsak vojak dragocenost, saj morajo države veliko narediti za njegovo izobrazbo, usposabljanje, opremo in oborožitev. Uspešen vojaški sistem vodenja in poveljevanja temelji na pozitivnih vidikih motiviranja pripadnic ter pripadnikov vojske, negativni vidiki pa morajo biti vključeni na način, ki ga pripadnice in pripadniki pojmujejo kot pošten ter pravičen. Poleg tega mora sistem vodenja in poveljevanja vključevati taka povelja, ki dajejo nižjim vojaškim 
poveljnikom možnost, da sami najdejo način, kako bodo opravili posamezno nalogo. Nižji vojaški poveljniki pridobijo z decentralizacijo vodenja možnost za kreativnost pri reševanju vojaških nalog, zaradi česar so uspešnejši in hkrati zadovoljnejši pri opravljanju vojaških nalog.

$\mathrm{V}$ prihodnosti bodo načela vodenja, ki temeljijo na medsebojnem zaupanju med podrejenimi in nadrejenimi vojaškimi poveljniki, standardizirani postopki operativnega delovanja, enotna izurjenost, zanesljivost, discipliniranost in sposobnost samostojnega delovanja zelo pomembni. Vodenje s poslanstvom ima pomembno vlogo tudi v sodobnem bojevanju z elektronsko informacijsko podporo. Kljub novi tehnologiji ostaja bistvenega pomena, da so vojaki sposobni sprejemati odločitve na bojišču v skladu s poveljnikovo namero. Vojaki morajo biti torej dovolj usposobljeni, da zmorejo delovati na bojišču kot neodvisne osebe tudi, če izgubijo stik z nadrejenim, po drugi strani pa jim morajo nadrejeni zaupati, da bodo uspešno opravili nalogo tudi brez natančnih navodil (Widder, 2002). Za sodobno bojevanje se zdi najbolj problematičen vidik vodenja s poslanstvom premagovati razlike med starejšimi in mlajšimi generacijami v obvladovanju sodobne elektronske tehnologije. $\mathrm{Na}$ tej točki lahko pričakujemo težave, ki jih je mogoče preseči s sistematičnim urjenjem, izobraževanjem in usposabljanjem.

Sklep V raziskavi smo obe $\mathrm{v}$ začetku postavljeni hipotezi potrdili. Proces vojaškega vodenja in poveljevanja med prvo svetovno vojno je bil neučinkovit, zato so Nemci uvedli novosti $\mathrm{v}$ smislu decentralizacije vojaškega vodenja in poveljevanja, kar so uporabili v 12. ofenzivi na soški fronti. Glavni razlog za centraliziran sistem vojaškega vodenja in poveljevanja je bil velik strah vodilnih na generalštabih pred pojavom dezerterstva in vojaškega uporništva. V vojskah je bila do 19. stoletja glavna težava, kako preprečiti množično dezerterstvo vojakov in neposlušnost vojaških ukazov. Rešitev so vojske večinoma iskale v vojaškem drilu, urjenju in zahtevah po brezpogojni poslušnosti ter pokornosti vojakov zahtevam nadrejenih častnikov. Sistem je bil na bojiščih večinoma uspešen, dokler se niso pojavile milijonske vojske z napredno oborožitvijo. Te vojske so za generalštabe pomenile manjšo preglednost in nadzor nad dogajanjem na bojišču. Vojaška vodstva se niso zavedala, da se z decentralizacijo vojaškega vodenja in poveljevanja tudi zvišuje motiviranost moštva za bojevanje. Nižji vojaški poveljniki pridobijo z decentralizacijo vodenja možnost za kreativnost pri reševanju vojaških nalog, zaradi česar so uspešnejši in hkrati zadovoljnejši pri opravljanju vojaških nalog. Prav tako se vojaška vodstva niso zavedala pomena propagande, ki je s poudarjanjem nacionalnih čustev in nacionalne gorečnosti bistveno prispevala $\mathrm{k}$ večji motivaciji vojske za boj. Generalštabi se v prvi svetovni vojni še niso zavedali, da bistveno več dosežemo s pozitivnimi načini motiviranja kot negativnimi, med katere spadajo predvsem krute kazni in v skrajni fazi celo decimiranje. Negativni prijemi v sistemu vodenja in poveljevanja, ki temeljijo na zelo nasilnih kaznih, so imeli več negativnih posledic kot pozitivnih. To se je izrazito pokazalo v 12. soški ofenzivi, saj je prišlo do množičnega dezerterstva italijanske vojske. To je bil predvsem odgovor na neučinkovit sistem vodenja in poveljevanja, ki ga je uporabljala italijanska vojska pod generalom Cadorno. 


\section{Literatura}

1. Beckett, F. W. I., 2001. The Great War 1914-1918. Modern Wars in Perspective. Pearson Education Limited and Associated Companies throughout the world.

2. Beyeri, B., 1998. Kein »Wunder von Karfreit«. Wiener Zeitung. 19. 5. 1998. http://www. wienerzeitung.at/themen_channel/wz_reflexionen/kompendium/382157_Kein-Wundervon-Karfreit.html, 10. 8. 2017.

3. Bull, S., 2007. German Assault Troops of the First World War. Stosstrupptaktik. Goucestershire: Spellmount.

4. Bungay, S., 2011. Moltke - Master of Modern Management. http://www. europeanfinancialreview.com/? $p=2953$, 20. 9. 2017.

5. Cheney, D., 2016. The Moral Verdict and Military Effectiveness of Decimation Upon the Roman Army. http://www.twcenter.net/forums/showthread.php?736839-The-MoralVerdict-and-Military-Effectiveness-of-Decimation-Upon-the-Roman-Army, 21. 8. 2017.

6. Van Creveld, M., 1985. Command in War. Cambridge, Massachusetts and London: Harvard University Press.

7. Dupuy, N. T., 1011. Der Genius des Krieges. Das deutsche Heer und der Generalstab 1807-1945. Graz: Ares Verlag.

8. Erminger, S., 2010. Auftragstaktik - Eine militärische Führungskonzeption in der Entwicklung deutscher Militärgeschichte vom 18. Jahrhundert bis in unsere Zeit. Norderstedt: GRIN Verlag.

9. Farina, J., 1998. Caporetto. A Fresh Look. www.worldwarl.com/itafront/caporetto.htm, 29. 8. 2017.

10. Gunther, J. M., 2012. Auftragstaktik: The Basis for Modern Military Command? http:// cgsc.contentdm.oclc.org/cdm/ref/collection/p4013coll3/id/2963, 20. 9. 2017.

11. Kent, G., 2013. On the run. Deserters through the ages. London: The Robson Press.

12. Lexikon Erster Weltkrieg. Schlacht bei Caporetto. http://www.lexikon-erster-weltkrieg.de/ Schlacht_bei_Caporetto, 20.9. 2017.

13. Liaropoulos, N. A., 2010. Revolutions in Warfare: Theoretical Paradigms and Historical Evidence - The Napoleonic and First World War Revolutions in Military Affairs. V War Studies Reader. London, New York: Continuum International Publishing Group, str. 129-157.

14. Lubi, D., 2007. Temelji vodenja in poveljevanja. Študijsko gradivo. Ljubljana: Fakulteta za družbene vede.

15. Mesesnel, J., 1987. Soška fronta. Ljubljana: Prešernova družba.

16. Morris, I., 2017. The Age of Modern Warfare. https://worldview.stratfor.com/article/agemodern-warfare, 28. 8. 2017.

17. Mosier, J., 2001. The Myth of the Great War. A New Military History of World War I. Hatton Garden: Profile Books.

18. Muhm, G., 2017. German Tactics in the Italian Campaign. http://www.larchivio.org/xoom/ gerhardmuhm2.htm, 20. 9. 2017.

19. Nečak, D., 2010. »Branilec Karpatov in Soče« Feldmaršal Svetozar Boroević de Bojna. O feldmaršalu Svetozarju Boroeviću de Bojni. Ljubljana: Znanstvena založba Filozofske fakultete Univerze v Ljubljani, str. 9-62.

20. Perry, M. J., 1996. Arrogant Armies. Great Military Disasters and the Generals Behind Them. Canada: John Wiley \& Sons.

21. Petelin, D. (ur.), 2006. Vojaška doktrina. Ljubljana: Defensor.

22. Potočnik, V., 2014. Poveljevanje z namero in Slovenska vojska. Sodobni vojaški izzivi. 16-2, str. 97-111.

23. Sheffield, G. D., 2005. Leadership in the Trenches. Officer-Man Relations, Morale and Discipline in the British Army in the Era of the First World War. Basingstoke: Palgrave Macmillan. 
24. Shot at Dawn. The Heritage of the Great War. http://www.greatwar.nl/frames/defaultshotatdawn.html, 25. 9. 2017.

25. Simčič, M., 2000. Zlom pri Kobaridu. Ljubljana: Karantanija.

26. Sweet, W. F., 2000. The Evolution of Rifle Tactics. Palm Coast: Backintyme Publishing.

27. Tacken, T., 2015. Luigi Cadorna and the fate of every tenth man. https:// thefirstworldwarin261weeks.com/2015/06/27/053-luigi-cadorna-and-the-fate-of-everytenth-man/, 21. 8. 2017.

28. Terraine, J., 2008. Essays on Leadership and War 1914-18. http://www. westernfrontassociation.com/the-great-war/great-war-on-land/john-terraine-essays-onleadership-and-war-1914-18/130-british-military, 28. 8. 2017.

29. Thompson, M., 2008. The White War. Life and Death on the Italian Front 1915-1919. London: Faber and Faber.

30. Walther, C., 2010. Was bewegt Soldaten? Zu Fragen soldatischer Mentalität. V Jahrbuch Innere Führung 2010 - Die Grenzen des Militärischen. Norderstedt: Carola Hartmann Miles Verlag, str. 51-61.

31. Widder, W., 2002. Battle Command: Auftragstaktik and Innere Fuhrung: Trademarks of German Leadership. Military Review. https://www.questia.com/library/ journal/1P3-218626241/battle-command-auftragstaktik-and-innere-fuhrung, 20. 9. 2017.

32. Wolf, U., 2010. Vernetzte Operationsführung - Das Ende der Auftragstaktik? V Jahrbuch Innere Führung 2010 - Die Grenzen des Militärischen. Norderstedt: Carola Hartmann Miles Verlag, str. 88-92. 